\title{
Pemberdayaan UKM Untuk Peningkatan Keterampilan dan Produksi Perak Pada Suryadi Silver
}

\author{
I Nyoman Yudi Anggara Wijaya ${ }^{*}$, Komang Tri Werthi ${ }^{2}$ \\ 1,2STMIK PRIMAKARA \\ * Penulis Korespondensi: E-mail: inyomanyudi@gmail.com
}

\begin{abstract}
Silver is one of the handicrafts made from pure metal formed into various types of jewelry such as rings, bracelets, necklaces, earrings, hair ornaments and there are still several other types which are processed with the base material of pure metal which is processed into various kinds silver jewelery One of the silver craftsmen is a partner in the Community Partnership Program activities in the Sukawati Village, Gianyar Regency. Partners started a business in producing silver since 2010 and are still going on until now, several stages in the production of silver partners are still using traditional methods using traditional tools. This stage requires a long time so the production time is long enough. The obstacle that is often visited by partners now is the problem of production equipment, not yet having a product label for partner business information, for the product design that is produced there are still quite a few variations produced by this regarding partners who have quite a minimum ability to design products. Solutions that can be provided from the contest are announced to provide production assistance, product variety training and packaging labeling training for the products to be marketed. The results of this service have been provided with production equipment consisting of tumblers, ultrasound, drill tools and product variation training. Labeling packaging has been given a design label for each packaging.
\end{abstract}

Keywords: Silver, Crafts, Products, Community Service

\begin{abstract}
Abstrak
Perak merupakan salah satu kerajinan yang berbahan dasar dari logam murni yang dibentuk menjadi beraneka macam perhiasan seperti cincin, gelang tangan, kalung, anting-anting, hiasan rambut dan masih ada beberapa jenis lainnya yang diolah dengan bahan dasar logam murni yang diolah menjadi aneka perhiasan perak. Salah satu pengerajin perak adalah mitra dalam kegiatan Program Kemitraan Masyarakat yang berada di Desa Sukawati Kabupaten Gianyar. Mitra memulai usaha dalam memproduksi perak sejak Tahun 2010 dan masih berlangsung sampai saat ini, beberapa tahapan dalam produksi perak mitra masih menggunakan cara tradisional dengan menggunakan alat tradisional. Tahapan ini tentunya membutuhkan waktu yang lama sehingga waktu produksi cukup lama. Kendala yang sering dialami mitra saat ini adalah keterbatasan alat produksi, belum memiliki label produk untuk informasi usaha mitra, untuk desain produk yang dihasilkan masih cukup sedikit variasi yang dihasilkan hal ini dikarenakan mitra memiliki kemampuan yang cukup minim untuk mendesain produk. Solusi yang dapat diberikan dari permasalahan yang dijabarkan adalah dengan memberikan bantuan alat produksi, pelatihan variasi produk dan pelatihan labeling kemasan untuk produk-produk yang akan dipasarkan. Hasil dari kegiatan pengabdian ini telah diberikan alat produksi berupa tumbler, ultrasonik, alat bor dan pelatihan variasi produk. Untuk labeling kemasan telah diberikan pelatihan desain label untuk masing-masing kemasan.
\end{abstract}

Kata kunci: Perak, Kerajinan, Produk, Pengabdian Masyarakat 


\section{PENDAHULUAN}

Pembangunan industri merupakan salah satu rangkaian dari pelaksanaan pembangunan daerah Bali. Pemikiran untuk mengembangkan sektor industri, khususnya industri kecil dan menengah di Provinsi Bali dapat dipandang sebagai upaya yang sangat strategis dan rasional mengingat usaha ini amat beraneka ragam, dapat disesuaikan dengan potensi dan kondisi sumber daya alam serta sumber daya manusia yang tersedia. Pembangunan nasional memliki tujuan - tujuan untuk mensejahterakan dan memakmurkan masyarakat indonesia. Kesejahteraan masyarakat dalam suatu daerah merupakan tujuan dari pembangunan (Yasa,2015). Logam merupakan salah satu bahan dasar yang dapat dijadikan perhiasan atau produk-produk kerajinan yang dapat dipasarkan serta dijadikan cendramata untuk wisatawan (Astiti,2010). Harga untuk produk berbahan dasar logam cukup terjangkau untuk masyarakat berkisar antara Rp 100.000 - Rp 800.000 disesuaikan dengan bentuk dan jenis kerajinan tersebut. Salah satu produk yang berbahan dasar logam adalah perak. Perak merupakan salah satu kerajinan yang diolah menjadi berbagai macam bentuk perhiasan, dimana perak yang dikombinasikan dengan menambahkan batu alam untuk mempercantik perhiasan tersebut, adapun perhiasan yang dihasilkan antara lain anting-anting, kalung, gelang, cincin, hiasan rambut serta produk perhiasan lainnya. Perak menjadi salah satu kerjainan yang digemari oleh masyarakat maupun wisatawan asing khususnya untuk wanita. Bapak I Ketut Suweca yang merupakan mitra dalam kegiatan PKM (Program Kemitraan Masyarakat) pada pengabdian masyarakat ini.

Bapak I Ketut Suweca memulai usahanya pada tahun 2010 sampai dengan saat ini, usaha ini dirintis bersama keluarga dan dibantu oleh 4 orang karyawan. Usaha perak Bapak I Ketut Suweca mengalami masa pasang surut dimana hal ini dikarenakan oleh mulai banyaknya persaingan perak dari pengerajin di Desa tersebut. Pada tahun 2015 mitra mengalami penurunan produksi disebabkan oleh persaingan yang tinggi serta minimnya pengetahuan mitra tentang pemasaran dan variasi desain produk. Namun kini mitra memulai kembali usaha dengan mengeluarkan produk-produk terbaru, permasalahan yang saat ini dialami oleh mitra adalah minimnya jumlah alat produksi yang dimiliki untuk proses produksi yang menyebabkan mitra tidak dapat menerima pesanan dalam jumlah banyak serta waktu penyelesaian produk pun membutuhkan waktu yang cukup lama. Pada pengemasan untuk saat ini mitra hanya menggunakan kemasan plastik untuk produk yang berukuran kecil serta kotak tanpa label untuk produk yang ukuran sedang. Dengan pengemasan yang digunakan saat ini memiliki kendala dimana mitra tidak dapat memberikan informasi kepada konsumen bahwa produk tersebut merupakan hasil karya dari Bapak I Ketut Suweca . Proses pemasaran saat ini masih menggunakan sistem tradisional mengerjakan perak sesuai pesanan dan terkadang mitra menitipkan di pasar tradisional yang menjadi pusat oleh-oleh disekitaran Desa tersebut. Kendala yang terjadi dengan proses pemasaran tersebut konsumen tidak mengetahui informasi jelas tentang tempat produksi dan jika konsumen berkeinginan untuk membeli kembali produk tersebut tidak dapat menghubungi pengerajin dikarenakan informasi dalam produk yang dikemas tidak tercantum informasi alamat serta nama usaha mitra. Mitra berlokasi di Desa Celuk Kabupatek Gianyar dengan jarak lokasi dari lokasi pengusul ke lokasi mitra sekitar sekitar $\pm 18 \mathrm{~km}$. Analisis situasi mitra Bapak I Ketut Suweca mulai dari alat produksi, manajemen pemasaran. 
Kondisi mitra Bapak I Ketut Suweca dapat dilihat seperti pada gambar dibawah ini:

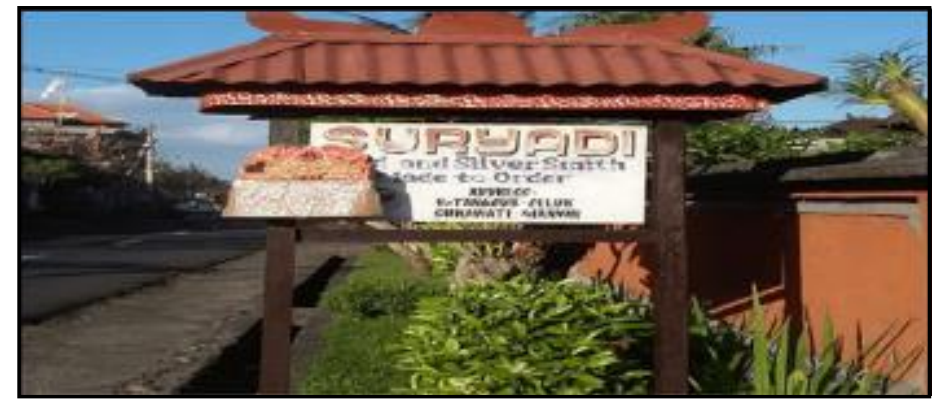

Gambar 1. Papan Nama Usaha Mitra "Suryadi Silver"

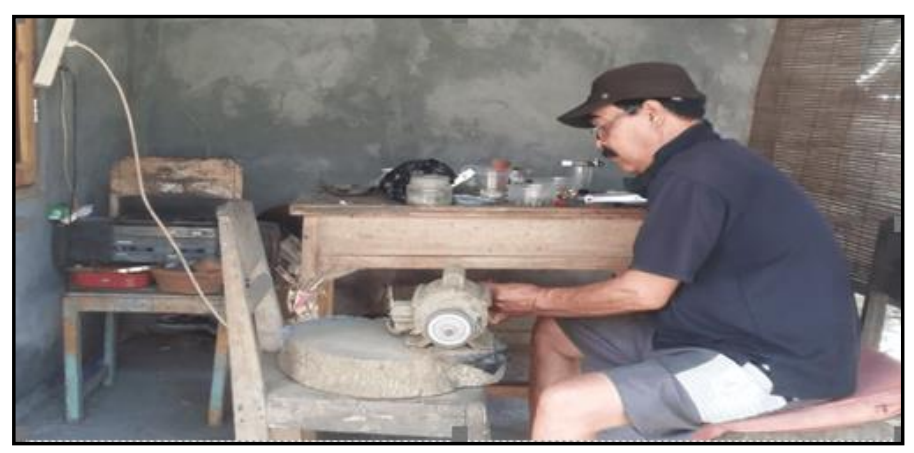

Gambar 2. Kondisi Tempat Kerja

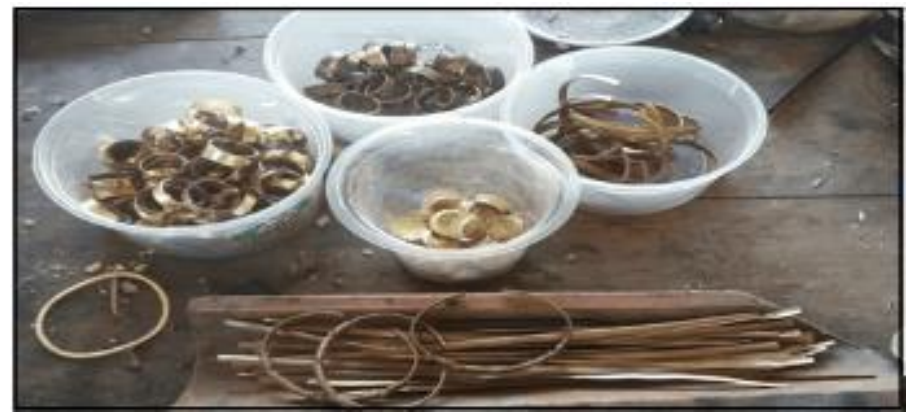

Gambar 3. Perak Setelah Proses Pembakaran 


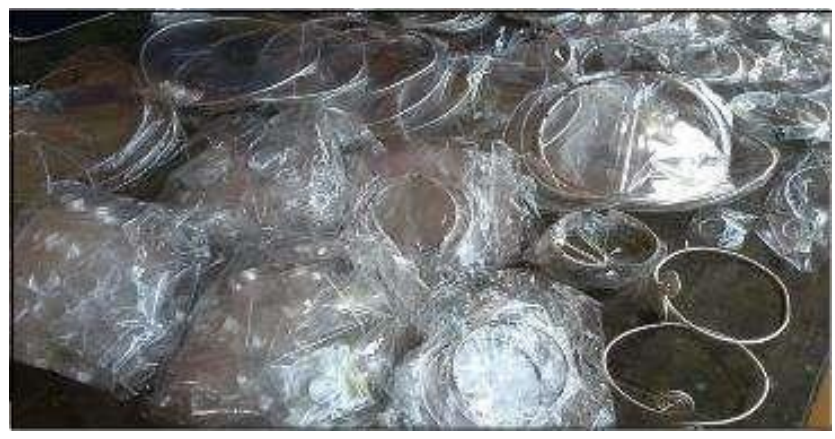

Gambar 4. Pengemasan Produk dengan plastik bening

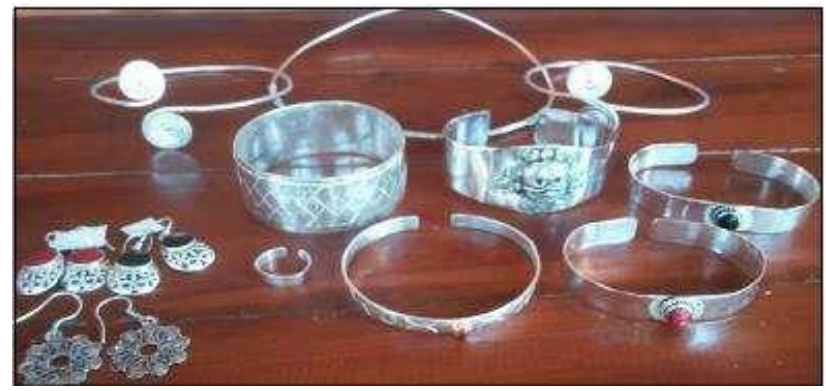

Gambar 5. Produk mitra yang akan dipasarkan

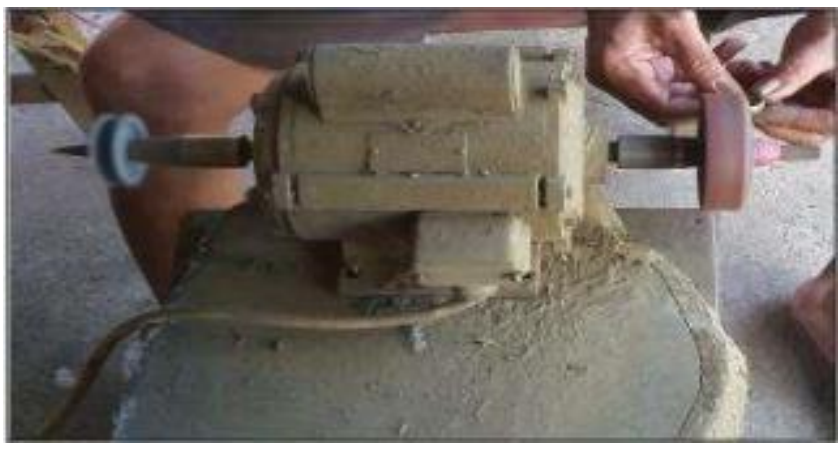

Gambar 6. Alat produksi mesin

Dari analisis situasi kondisi mitra yang telah dijabarkan diatas maka dapat diambil beberapa permasalahan yang dihadapi oleh mitra dan menjadi prioritas sebagai berikut:

1. Produksi mitra tidak menentu disesuaikan dengan pesanan mitra dan ketersediaan alat produksi.

2. Pendapat mitra tidak menentu disesuaikan dengan jumlah produksi yang dapat dipasarkan saat itu.

3. Pemesanan perak dengan jumlah yang besar dan waktu yang singkat sampai saat ini belum dapat dikerjakan oleh mitra dikarenakan keterbatasan alat produksi.

4. Pengemasan masih menggunakan plastik bening tanpa label usaha mitra.

Solusi dari permasalahan yang telah dijabarkan dalam pendahuluan diatas, dalam kegiatan pengabdian masyarakat ini akan memberikan bantuan penambahan alat produksi yang dibutuhkan untuk proses produksi, pelatihan labeling kemasan untuk membuat kemasan 
lebih menarik dan informative dengan peningkatan aspek pemasaran, pelatihan variasi produk untuk menambah jumlah variasi produk yang dihasilkan. Hasil atau luaran yang ingin dicapai dalam kegiatan pengabdian masyarakat ini adalah meningkatnya jumlah produksi mitra dengan bantuan yang diberikan yaitu penambahan dan penggantian alat produksi yang proses sebelumnya menggunakan proses yang manual atau tradisional. Dengan penambahan alat produksi diharapkan memberikan peningkatan dari jumlah produksi yang dihasilkan dan waktu pengerjaan lebih cepat. Capaian yang ingin dihasilkan dalam kegiatan ini adalah peningkatan produksi sebesar $100 \%$.

\section{METODE PELAKSANAAN}

Kegiatan pengabdian masyarakat ini memiliki metode dalam melaksanakan agenda kegiatan yang sudah direncanakan, adapun tahapan-tahapan atau metode yang dilakukan dalam kegiatan ini adalah seperti pada gambar berikut:

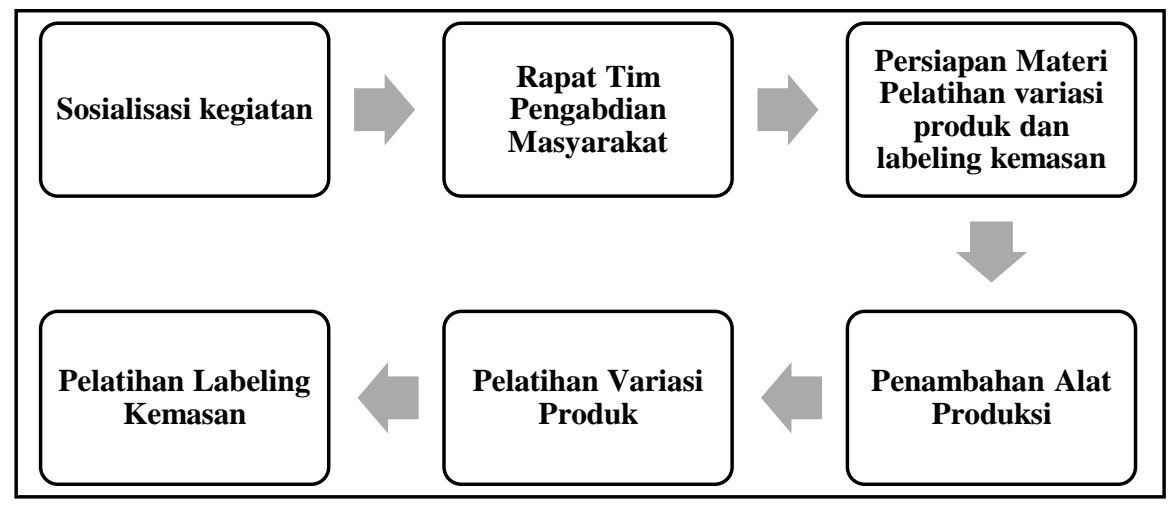

Gambar 7. Metode Pelaksanaan Pengabdian Masyarakat

\section{HASIL dan PEMBAHASAN}

Hasil dari kegiatan pengabdian masyarakat ini adalah penambahan alat produksi, pelatihan variasi produk dan pelatihan labeling kemasan, kegiatan pengabdian ini disusun sesuai dengan tahapan yang telah ditentukan dan kegiatan ini dimulai dari sosialisasi kegiatan pengabdian masyarakat dengan melakukan sosialisasi kegiatan dari tim pelaksana kegiatan pengabdian masyarakat dengan mitra. Kegiatan ini dilakukan untuk memberikan kesepakatan kegiatan dengan mempertimbangkan waktu kegiatan, jenis pelatihan, peralatan pendukung kegiatan dan peserta kegiatan pengabdian masyarakat dengan mempertimbangkan waktu yang digunakan kegiatan pengabdian masyarakat sesuai dengan keadaan dan kondisi mitra pada saat waktu yang cukup senggang dan memiliki waktu yang cukup untuk melakukan kegiatan yang telah ditentukan. Seluruh kegiatan yang disepakati adalah kegiatan yang dipilih oleh mitra dengan memperhatikan kebutuhan yang saat ini dibutuhkan oleh mitra. Sosialisasi dilakukan dalam waktu 1 hari dengan membahas kegiatan-kegiatan yang akan dilaksanakan. Tahap selanjutnya adalah tim pelaksana melakukan pembahasan tentang materi yang diberikan untuk pelatihan dan persiapan untuk pembelian alat untuk menambah alat produksi mitra.

Kegiatan selanjutnya yang merupakan rangkaian dari kegiatan pengabdian masyarakat ini adalah kegiatan pelatihan pembuatan materi tentang variasi produk dan label kemasan. Kegiatan ini dilakukan oleh tim pengabdian masyarakat dengan membuat materi yang akan 
diberikan mulai dari materi pelatihan variasi produk, dan pelatihan labeling kemasan. Tahapan ini dilaksanakan dengan mendiskusikan kegiatan pengabdian masyarakat dengan mitra. Kegiatan selanjutnya yaitu penambahan alat produksi mitra dalam kondisi sebelum dilakukan kegiatan pengabdian masyarakat ini adalah mitra melakukan proses pencucian produk yang telah dicetak dengan mencuci dan merebus menggunakan air hangat. Proses yang dilakukan tersebut melalui tahap berulang-ulang sampai dengan produk dinyatkan bersih tahap pertama dengan menggunakan obat pencuci untuk membersihkan hasil-hasil pembakaran produk. Proses pencucian produk dengan tahap tradisional membutuhkan waktu 3 sampai 4 jam jika dikerjakan dirumah, 1 hari pengerjaan jika dikerjakan di tempat pencucian perak dengan membayar biaya pencucian produk per biji produk yang akan dicuci. Penambahan alat yang diberikan dalam kegiatan pengabdian ini adalah mesin tumbler dengan kapasitas 10kg dengan menggunakan listrik. Keunggulan dan keuntungan alat yang diberikan ini kepada mitra adalah dengan alat ini mitra dapat melakukan pencucian produk perak yang telah diproduksi di rumah mitra dan membutuhkan waktu yang cukup singkat sekitar 1-2 jam pengerjaan dengan keunggulan dari mesin tumbler ini adalah alat ini dapat memutar sendiri tanpa harus dilakukan proses mencampur dan melihat dan menggati posisi pencucian. Dalam proses pencucian ini membutuhkan obat yang digunakan untuk mencuci dan jarum yang dapat membantu membersihkan secara maksimal. Ultrasonik digunakan untuk menggantikan tahapan tradisional yang dilakukan sebelumnya yaitu dengan melakukan pencucian produk dan membersihkan produk dari obat yang digunakan untuk mencuci pada tahap sebelumnya. Keunggulan dari alat ini memberikan waktu yang cukup singkat untuk proses pembersihan dan pencucian produk, sehingga mitra dapat melakukan proses produksi lainnya.

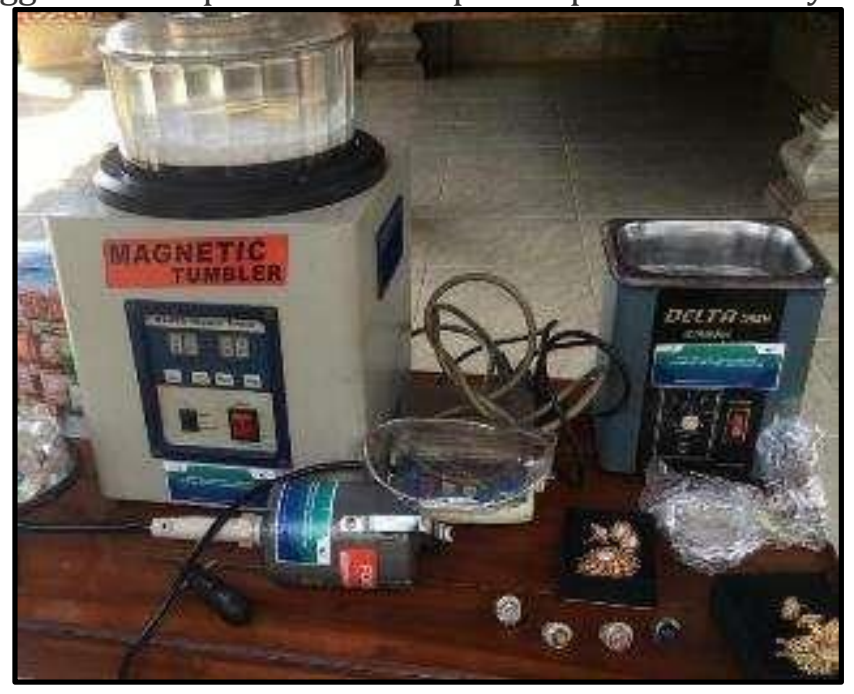

Gambar 8. Penambahan Alat Produksi

Alat selanjutnya yang diberikan adalah alat bor listrik yang dapat diguankan untuk menghaluskan hasil desain sebelum dilakukan proses pemasaran dengan alat sebelumnya digunakan alat bor dengan membawa ke tempat bor dan membayar biaya untuk bor tersebut. Dengan penambahan alat bor mitra dapat melakukan proses tersebut di lokasi mitra dengan mengurangi biaya jasa bor produk. Adapun hasil perbandingan kegiatan penambahan alat produksi dibandingkan dengan kondisi sebelumnya dapat digambarkan dalam tabel sebagai berikut: 
Tabel 1. Perbandingan Alat Produksi

\begin{tabular}{|c|c|c|c|}
\hline No & Nama Kegiatan & Alat Sebelumnya & Alat yang ditambahkan \\
\hline 1 & $\begin{array}{l}\text { Pencucian produk yang } \\
\text { telah di bakar }\end{array}$ & $\begin{array}{l}\text { Proses dilakukan dengan } \\
\text { merebus produk dengan } \\
\text { air hangat }\end{array}$ & $\begin{array}{l}1 \text { unit mesin tumbler, } 1 \text { unit } \\
\text { mesin ultrasonic, } 1 \text { set jarum } \\
\text { pencuci produk }\end{array}$ \\
\hline 2 & $\begin{array}{l}\text { Pembuatan produk dan } \\
\text { menghaluskan ukiran } \\
\text { produk perak }\end{array}$ & $\begin{array}{l}\text { Menggunakan palu dan } \\
\text { alat yang runcing untuk } \\
\text { membuat bentuk lebih } \\
\text { detail }\end{array}$ & 1 unit bor listrik \\
\hline
\end{tabular}

Perbandingan jumlah produksi produk yang telah dihasilkan sebelum penambahan alat produksi dan setelah dilakukan penambahan alat produksi belum mengalami peningkatan yang cukup tinggi dikarenakan pemesanan dengan jumlah besar untuk saat ini belum ada sehingga belum dapat mengukur kapasitas produksi yang dapat di kerjakan. Dalam jumlah kecil produk yang dapat diproduksi untuk saat ini setelah diberikan penambahan alat produksi dapat memproduksi lebih dari 50 produk. Perbandingan waktu pengerjaan produk sebelum dilakukan kegiatan pengabdian masyarakat dan setelah dilakukan kegiatan pengabdian masyarakat adalah sebagai berikut:

Tabel 2. Perbandingan Waktu Pengerjaan

\begin{tabular}{llll}
\hline No & $\begin{array}{l}\text { Nama } \\
\text { Produk }\end{array}$ & $\begin{array}{l}\text { Waktu Pengerjaan Sebelum } \\
\text { Kegiatan Pengabdian } \\
\text { Masyarakat }\end{array}$ & $\begin{array}{l}\text { Waktu Pengerjaan Setelah } \\
\text { Kegiatan Pengabdian } \\
\text { Masyarakat }\end{array}$ \\
\hline 1 & Cincin & 7 hari pengerjaan & 5 hari pengerjaan \\
2 & Gelang & 7 hari pengerjaan & 5 hari pengerjaan \\
3 & Anting & 7 hari pengerjaan & 5 hari pengerjaan \\
\hline
\end{tabular}

Pelatihan variasi produk diberikan untuk menambah pengetahuan mitra terhadap desain-desain terbaru dengan mempertimbangkan minat konsumen saat ini. Produksi perak yang diproduksi saat ini dengan memberikan tema naga, ukir-ukiran barong sesuai dengan konsep ukiran Bali. Dalam kegiatan variasi produk mitra diberikan pelatihan tentang pembuatan liontin kalung untuk menambah variasi produk yang sebelumnya mitra tidak memproduksi kalung dengan liontin. Produk-produk yang dihasilkan mitra adalah: gelang tangan, cincin, bros. Kegiatan pelatihan variasi produk dilakukan 3 hari dengan memberikan variasi pelatihan desain cincin dan pelatihan desain liontin untuk variasi produk. Kegiatan ini sangat antusias dilakukan oleh peserta pengabdian masyarakat. Hasil dari kegiatan variasi produk ini adalah sebagai berikut: 


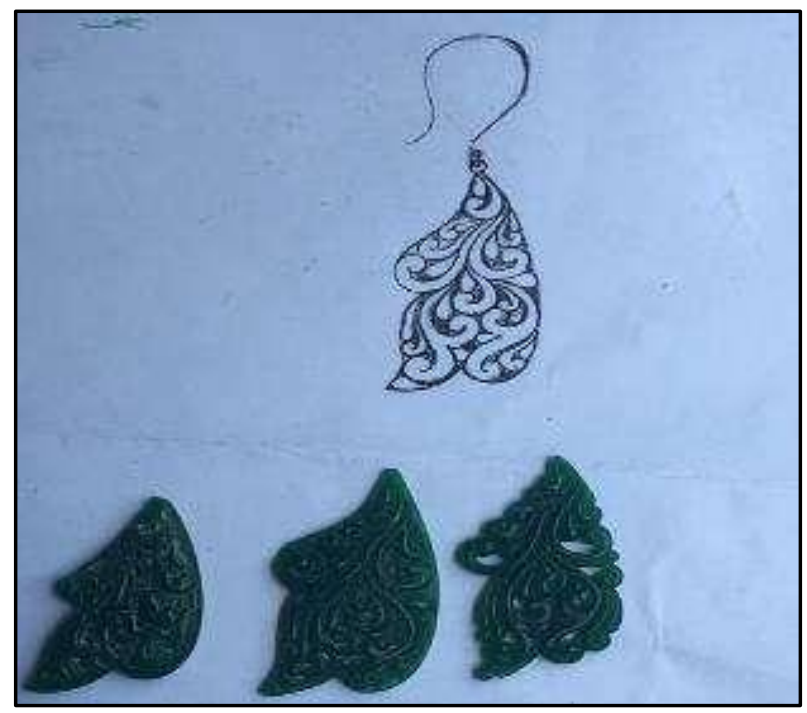

Gambar 9. Hasil Kegiatan Variasi Produk

Pelatihan labeling kemasan dalam kegiatan pelatihan ini dilakukan oleh mitra dan peserta pelatihan kegiatan pengabdian masyarkat. Dalam kegiatan pengabdian masyarakat ini memberikan informasi tentang nama usaha mitra informasi. Hal ini digunakan untuk memberikan informasi tentang lokasi usaha mitra dan informasi yang dapat digunakan oleh konsumen saat akan melakukan pemesanan barang kembali ke usaha mitra. Adapun label kemasan yang dihasilkan dari kegiatan ini adalah sebagai berikut:

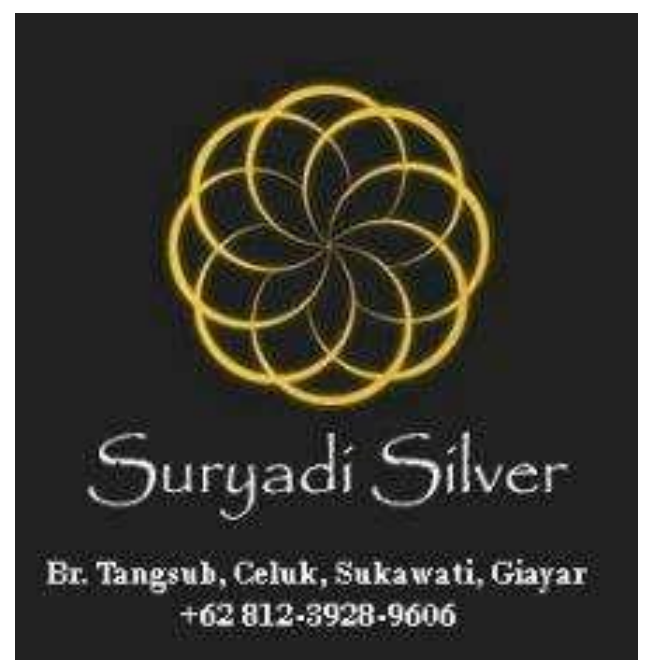

Gambar 10. Labeling Kemasan

\section{UCAPAN TERIMAKASIH}

Terimakasih kami ucapakan kepada LPPM STMIK PRIMAKARA yang telah memfasilitasi dan membantu dalam proses surat menyurat untuk kegiatan pengabdian masyarakat. 
Terimakasih juga kami ucapkan kepada RISTEK DIKTI yang telah memberikan dana untuk kegiatan pengabdian masyarakat ini dengan Hibah Program Kemitraan Masyarakat.

\section{KESIMPULAN}

Kesimpulan dari kegiatan pengabdian masyarkat ini dengan dana Hibah Skema Program Kemitraan Masyarakat adalah bertambahnya alat produksi mitra yaitu mesin bor listrik, mesin tumbler yang digunakan untuk mencuci produk yang telah melalui tahap pencetakan, dan ultrasonic yang digunakan untuk pencucian tahap terakhir untuk memberikan warna lebih berkilau pada produk. Pelatihan variasi produk memberikan penambahan wawasan mitra dalam memproduksi variasi produk kalung dan cincin dengan konsep desain yang menarik. Pelatihan labeling kemasan mengasilkan desain logo usaha mitra dan informasi tentang usaha mitra yang dapat digunakan untuk media pemasaran mitra.

\section{DAFTAR PUSTAKA}

Yasa,I Komang Antara.,\&SUdarsana Arka. (2015). Pengaruh Pertumbuhan Ekonomi dan Disparitas Pendapatan Antar daerah Terhadap Kesejahteraan Masyarakat Provinsi Bali.Jurnal Ekonomi Kuatitatif Terapan. Vol 8 No.1 Februari 2015.

Dinas Perindustrian dan Perdagangan Kabupaten Gianyar, (2015).

Astiti, Putu Yulia. 2010. Analisis Skala Ekonomi Usaha Kerajinan Perak Di Kecamatan

Sukawati Kabupaten Gianyar. Universitas Udayana Denpasar.

Udiana, Ni Wayan Pradnyana Paramitha. (2017). Analisis Pendapatan Pengerajin Perhiasan di Desa Celuk (Studi Perbandingan Pengerajin Perak dan Pengerajin Alpaka). Jurnal Ekonomi Pembangunan Udayana. Vol 6 No 8 Agustus 2017. 